\title{
Characterizing edaphoclimatic variables in sites hosting natural Brazil nut tree populations in Mato Grosso state
}

\author{
Silvio Tulio SPERA ${ }^{1}$, Aisy Botega BALDONI ${ }^{*}$, Ciro Augusto de Souza MAGALHÃES ${ }^{1}$, \\ Jorge LULU1 ${ }^{1}$, Helio TONINI², Cornélio Alberto ZOLIN¹', Maurel BEHLING ${ }^{1}$
}

\author{
${ }^{1}$ Embrapa Agrossilvipastoril, Sinop, MT, Brasil. \\ (ORCID: 0000-0001-5344-7509; *; 0000-0002-7899-8566; 0000-0001-7040-771X; 0000-0003-3028-8722; 0000-0002-4191-5915) \\ ${ }^{2}$ Embrapa Pecuária Sul, Bagé, RS, Brasil. (ORCID: 0000-0003-1123-7604) \\ *E-mail: aisy.baldoni@embrapa.br (ORCID: 0000-0002-8355-6957)
}

\begin{abstract}
Recebido em 26/11/2019; Aceito em 22/05/2020; Publicado em 10/06/2020.
ABSTRACT: The edaphoclimatic environment typical of sites hosting Brazil nut in Northern Mato Grosso State was investigated in the current study. Average climate elements at monthly scale (accumulated rainfall, mean, maximum and minimum air temperatures, mean relative air humidity, and water balance) and edaphic variables (soil profile description, as chemical, particle-size and mineralogical analyses) were herein assessed. The study was conducted in four sites hosting Brazil nut trees in Itaúba, Alta Floresta, Juína and Cotriguaçu counties. Results indicated that the climate in the host region is characterized by mean accumulated rainfall $1,700 \mathrm{~mm}$ year ${ }^{-1}$ and maximum water deficit $390 \mathrm{~mm}$. The host sites present acidic soils, whose texture vary from sandy to very clayey, low natural fertility and high aluminum content. They also showed low spatial variability (accumulated rainfall, air temperature and relative air humidity) because they have similar tropical climate. Soils prevailing in the herein assessed sites belong to classes such as Dystrophics Red-Yellow Argisol and Red-Yellow Latosol, with flat to wavy relief. Based on rainfall amount during the dry season, water deficit and soil properties data in the assessed sites, regions such as Alta Floresta and Cotriguaçu showed favorable conditions for greater Brazil nut trees productivity, and may be indicated for the commercial planting of species. Key words: Bertholletia excelsa Bonpl.; chemical analyses; particle-size analyses; mineralogical analyses; accumulated rainfall.
\end{abstract}

\section{Caracterização de variáveis edafoclimáticas em locais de ocorrência de populações naturais de castanheira-do-Brasil no Mato Grosso}

\begin{abstract}
RESUMO: O ambiente edáfoclimático característico das áreas de ocorrência da Bertholletia excelsa no norte do estado de Mato Grosso foi estudado. Foram avaliadas as variáveis meteorológicas médias mensais (precipitação acumulada, temperatura do ar média, máxima e mínima e umidade relativa do ar média, e balanço hídrico) e as variáveis edáficas (descrição morfológica, análises químicas, granulométricas e mineralógicas). O estudo foi conduzido em quatro áreas de ocorrência de castanhais, nos municípios de Itaúba, Alta Floresta, Juína e Cotriguaçu. Os resultados indicaram que o clima na região é caracterizado por precipitação acumulada média de $1.700 \mathrm{~mm}_{\text {ano-1 }}$ e com déficit hídrico máximo de $390 \mathrm{~mm}$. Os solos das áreas de ocorrência das castanheiras são ácidos, de textura variando de arenosa a muito argilosa, de baixa fertilidade natural e alto teor de alumínio. Eles também mostraram baixa variabilidade espacial (precipitação acumulada, temperatura do ar e umidade relativa do ar). Os solos que prevalecem nos locais avaliados pertencem às classes de Argissolos VermelhoAmarelo e Latossolos Vermelho-Amarelo Distróficos, com relevo plano a ondulado. Com base na quantidade de chuvas durante a estação seca, dados de déficit hídrico e propriedades do solo destes locais avaliados, regiões como Alta Floresta e Cotriguaçu contemplam condições favoráveis para o cultivo da espécie.

Palavras-chave: Bertholletia excelsa Bonpl.; análises químicas; análises granulométricas; análises mineralógicas; precipitação acumulada.
\end{abstract}

\section{INTRODUCTION}

Brazil nut tree (Bertholletia excelsa Bonpl.) is one of the most important Amazonian extractive exploitation species; its seeds have high nutritional and commercial value, its fruits are used in handicrafts and an important part of the nut harvest is exported to developed countries were they are used by the cosmetics and food industry (ROCKWELL et al., 2015).

Mato Grosso State was the fifth largest national Brazilian nut producer $-6.51 \%$ of the national production in 2017 .
The production is concentrated in 21 counties located in the Northern region of the state and supplies the regional and national markets (IBGE, 2017).

The species grows in firm high forest lands, almost often in places difficult to be accessed, and its natural dispersion ranges from the upper Orinoco (latitude $5^{\circ} \mathrm{N}$ ) to the upper Beni (latitude $14^{\circ} \mathrm{S}$ ) - an area comprising Venezuela, Colombia, Peru, Bolivia, as well as the French and British Guyana. However, the most numerous compact formations comprising this species are located in Brazilian lands, in states 
such as Rondônia, Roraima, Pará, Maranhão, Mato Grosso, Amazonas and Acre (LORENZI, 2016). In addition, the species is mainly found in dystrophic, well-structured and well-drained soils, such as the clayey or sandy-clayey ones, and its highest occurrence is found in medium-to-clayey texture soils. The species is not found in poorly drained areas or in excessively thickened soils. Although many studies mentioned that the species grows in sandy-clayey soils, Guerreiro et al. (2017) indicated the existence of Brazil nut tree in sandy soil areas, and this paper confirm.

With respect to the climatic characterization of the sites hosting Brazil nut trees, the literature reports that tree grows in areas from sea level to approximately 400 meters with an annual mean temperature of 23.5 to $27.6{ }^{\circ} \mathrm{C}$, relative humidity ranging from $79 \%$ to $86 \%$, annual rainfall ranging from 1,445 to $3,399 \mathrm{~mm}$ and the negative soil water balance for 2 to 5 months (BRIENEN; ZUIDEMA, 2005; THOMAS et al., 2014).

Although data about climate variability and soil fertility in areas hosting Brazil nut trees are extremely relevant to Mato Grosso State, they remain scarce, fact that makes it difficult managing and conserving the species. Such data, in turn, are crucial and could help better understanding some plant processes related to fruit production and to its oscillation over the years, as well as understanding phenological processes in ecological studies. These data could also help developing future forest management and reforestation programs with the species.

It is expected that the edaphoclimatic characteristics in the region of natural occurrence of the species in Mato Grosso State vary significantly and it is expected that some regions have greater productive potential than others do. Therefore, the aim of the present study was to assess the edaphoclimatic features in areas hosting Brazil nut trees, in Northern Mato Grosso State, in order to provide subsidies for forest management, reintroducing and planting programs.

\section{MATERIALS AND METHODS}

Meteorological and soil data were assessed in areas hosting Brazil nut trees, in four counties located in Northern Mato Grosso State - Itaúba, Alta Floresta, Cotriguaçu and Juína - (Figure 1); within the area embraced by the Amazon biome.

The climate characterization comprised a 10-year period - from January 2007 to January 2017. Accordingly, the Agrometeorological Monitoring System (Agritempo) of Embrapa provided historical series concerning mean monthly rainfall; minimum, mean and maximum temperatures; and relative humidity $(\mathrm{RH})$, which were analyzed in order to identify discrepant data, as well as to fill in possible gaps. In addition, the Water Balance (WB) proposed by Thornthwaite (1948) was prepared.

Itaúba County did not have meteorological station to provide data series; thus, monthly rainfall data estimated by the Tropical Rain Meteorological Mission (TRMM) were used in the current study. These data comprised the period from January 1st, 2007 to November 1st, 2016, since the mission was terminated in December 2016. The TRMM provides data about 11,332 grid points, which are converted by the Agritempo system into the so-called Virtual Stations (VS). Thus, the VSs included in the aforementioned county's territory were herein used. The monthly temperature and mean RH data were estimated through interpolations in the QGIS 2.6 software, according to the Inverse Distance Weighting (IDW) method.

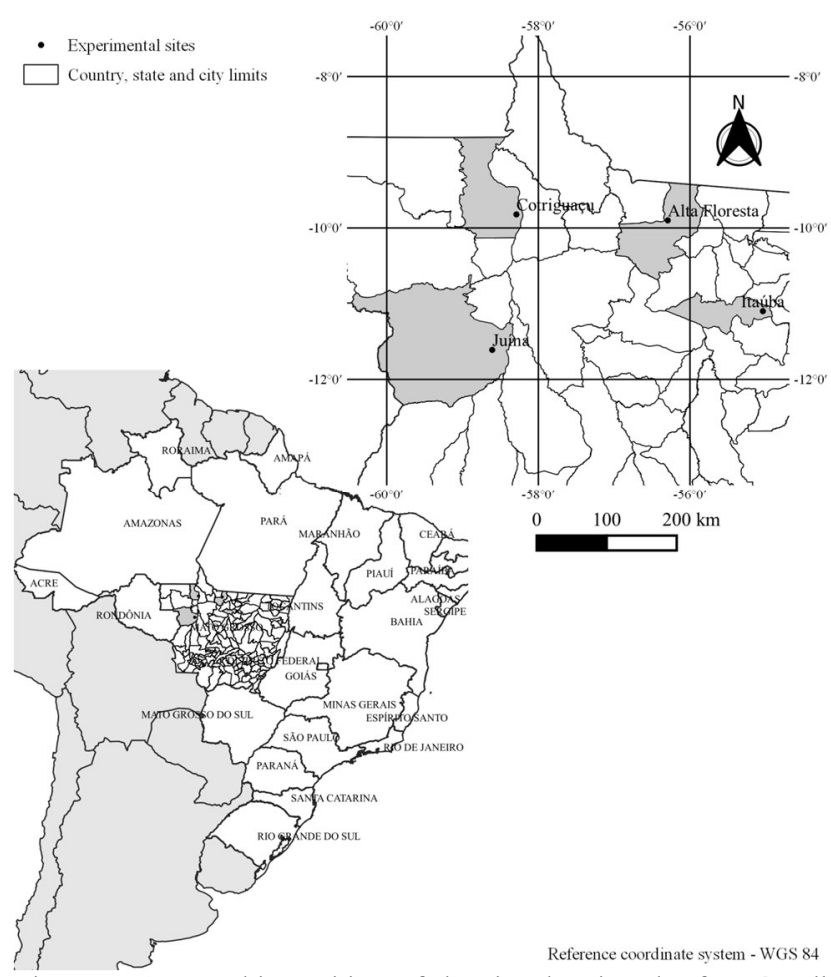

Figure 1. Geographic position of the sites hosting the four Brazil nut tree populations assessed in the current study.

Figura 1. Posição geográfica dos locais de ocorrência das quatro populações de castanheira-do-Brasil avaliadas.

The morphological features of soils in sites hosting Brazil nut trees were assessed through the pedological description of soil profiles in the four herein studied sites, according to Embrapa (2013), as well as through the classification of the soil in each site at subgroup level, according to the classification by Embrapa (2013). The soils were described in trench profiles (1.5 m wide; 1.0 to $2.7 \mathrm{~m}$ deep). Soil colors were described according to the Munsell soil color charts.

Two trenches were opened in Juína and Cotriguaçu Counties, one in Itaúba and Alta Floresta. One of the trenches (Plinthosol Argiluvic Dystrophic Arenic) was useful to explain the lack of Brazil nut trees in a site where the species often grows in, i.e., the presence of a superficial water table. The trenches in Cotriguaçu County were opened in two distinct sites, which were known for hosting Brazil nut trees.

The soil physical characterization of the profiles analyzed sand, silt and clay, whereas the chemical characterization analyzed water $\mathrm{pH}$, phosphorus, potassium, calcium, magnesium, exchangeable acidity $\left(\mathrm{Al}^{3+}\right)$, potential acidity $(\mathrm{H}$ $+\mathrm{Al})$ and organic carbon. The herein used methods were; $\mathrm{P}$ and $\mathrm{K}$, Mehlich ${ }^{-1}$; $\mathrm{Ca}, \mathrm{Mg}$ and $\mathrm{Al}: \mathrm{KCl} 1 \mathrm{~mol} \mathrm{~L}^{-1} ; \mathrm{H}+\mathrm{Al}: 0.5$ mol L-1 calcium acetate at $\mathrm{pH}$ 7.0; organic matter in the soil: Walkley and Black, according to (SILVA, 2009).

The $\mathrm{SiO}_{2}, \mathrm{Al}_{2} \mathrm{O}_{3}, \mathrm{Fe}_{2} \mathrm{O}_{3}$ and $\mathrm{TiO}_{2}$ contents and the $\mathrm{SiO}_{2} / \mathrm{Al}_{2} \mathrm{O}_{3} \quad(\mathrm{Ki}), \quad \mathrm{SiO}_{2} / \mathrm{R}_{2} \mathrm{O}_{3} \quad(\mathrm{Kr})$ and $\mathrm{Al}_{2} \mathrm{O}_{3} / \mathrm{Fe}_{2} \mathrm{O}_{3}$ molecular reactions were found after the samples were subjected to sulfuric acid digestion, according to Teixeira et al. (2017), and used in the soil mineralogical characterization. The lithology, of the geological formation and the originating material were identified according to the map by the Secretary 
of State Planning and General Coordination of Mato Grosso (CAMARGO, 2011).

The clay fraction $(\varnothing<0.002 \mathrm{~mm})$ was separated at Embrapa Solos Soil Physics Laboratory, according to Teixeira et al. (2017). The samples were analyzed under "natural" conditions and under the following treatments: deferrification by DCB (dithionite-citrate-sodium bicarbonate), according to Mehra; Jackson (2013); potassium saturation and heating at $110^{\circ}, 350^{\circ}$ and $550^{\circ}$ for two hours, after the slides were prepared; magnesium saturation and solvation in ethylene glycol, according to Teixeira et al. (2017). The slides were prepared in an oriented manner using the smear method.

Device specifications were: Rigaku diffractometer, Miniflex II model, radiation: $\mathrm{Cu} \mathrm{K} \alpha \ldots \lambda=0.154 \mathrm{~nm}$. Configuration was: without filter with graphite monochromator; slits: $1.25^{\circ} \mathrm{DS}$; $0.3 \mathrm{~mm} \mathrm{RS}$; $1.25^{\circ} \mathrm{SS}$. Programming conditions were: irradiation power: $30 \mathrm{kV}$ and $15 \mathrm{~mA}$; scanning interval: $2^{\circ}$ to $45^{\circ}(2 \alpha)$; counting unit: cps; time constant: 1 sec., step: $0.050^{\circ}$. Diffractograms were generated in the Microcal Origin 6.0 software and presented in the following order: untreated sample (Am.total); deferrified, magnesium-saturated sample subsequently solvated in ethylene glycol (MgEG); deferrified, potassiumsaturated sample subjected to readings at room temperature (K25) and, after heating, at marked temperatures (K110, $\mathrm{K} 350$ and K550).

Diffractogram interpretations were based on the JCPDSICDD database and on Berry (1974) tables, as well as on tables and criteria by Grim (1982), Barnhisel; Bertsch (1989) and Kämpf; Curi. (2003). The spelling of the names of the minerals complies with Branco (2008).

\section{RESULTS}

The studied sites showed similar climate features during the analyzed period (Table1) they showed low spatial variability due to their similar tropical climate (Aw and Am types), according to Köppen's climate classification (ALVARES et al., 2014; SOUZA et al., 2013). The highest total rainfall values were recorded in Itaúba $(2,160 \mathrm{~mm})$ and Alta Floresta counties $(1,834 \mathrm{~mm})$, whereas Cotriguaçu and Juína counties presented close mean rainfall rates (the difference between these rates was $43 \mathrm{~mm}$ ). The air temperature values showed mean ranging from $26.0^{\circ} \mathrm{C}$ (Juína) to $26.3^{\circ} \mathrm{C}$ (Alta Floresta). The mean relative humidity values also showed slight variation among the studied sites; the highest value was recorded in Alta Floresta County $(70.4 \%)$, whereas the lowest one was recorded in Juína County $(69.6 \%)$.

All the studied sites have very similar trends in the monthly rainfall variations and in the water balance (deficit/excess) extract (Figure 2). Itaúba County recorded the highest rainfall and water excess values, mainly in December, January and February. On the other hand, Alta Floresta County recorded the highest rainfall values in the dry months (June, July and August), which, in turn, resulted in lower water deficit $(267 \mathrm{~mm})$ than that recorded in Itaúba (364 mm), Juína (374 mm) and Cotriguaçu counties (390 $\mathrm{mm}$ ). Relative Humidity values (Figure 2) also showed similar trends among the assessed sites. However, it is worth highlighting that the highest $\mathrm{RH}$ values were recorded in Cotriguaçu County in July, August and September.
Table 1. Average climatic data encompassing the period between January 2007 and January 2017 in the four studied sites hodting Brazil nut tree in Mato Grosso State.

Tabela 1. Dados climáticos médios envolvendo o período entre janeiro de 2007 a janeiro de 2017, em quatro locais de ocorrência da castanheira-do-brasil no estado de Mato Grosso.

\begin{tabular}{|c|c|c|c|c|}
\hline \multirow{2}{*}{ Climate element } & \multicolumn{4}{|c|}{ County } \\
\hline & $\mathrm{COT}^{1}$ & $\mathrm{JUI}^{2}$ & $\mathrm{AFL}^{3}$ & ITA $^{4}$ \\
\hline Mean rainfall (mm) & 1,562 & 1,605 & 1,834 & 2,160 \\
\hline $\begin{array}{l}\text { Mean air temperature } \\
\left({ }^{\circ} \mathrm{C}\right)\end{array}$ & 26.1 & 26.0 & 26.3 & 26.1 \\
\hline $\begin{array}{l}\text { Mean maximum air } \\
\text { temperature }\left({ }^{\circ} \mathrm{C}\right)\end{array}$ & 31.3 & 31.2 & 32.0 & 31.6 \\
\hline $\begin{array}{l}\text { Mean minimum air } \\
\text { temperature }\left({ }^{\circ} \mathrm{C}\right)\end{array}$ & 20.4 & 20.7 & 20.5 & 20.6 \\
\hline $\begin{array}{l}\text { Mean air relative } \\
\text { humidity }(\%)\end{array}$ & 71.0 & 69.6 & 70.4 & 70.3 \\
\hline
\end{tabular}
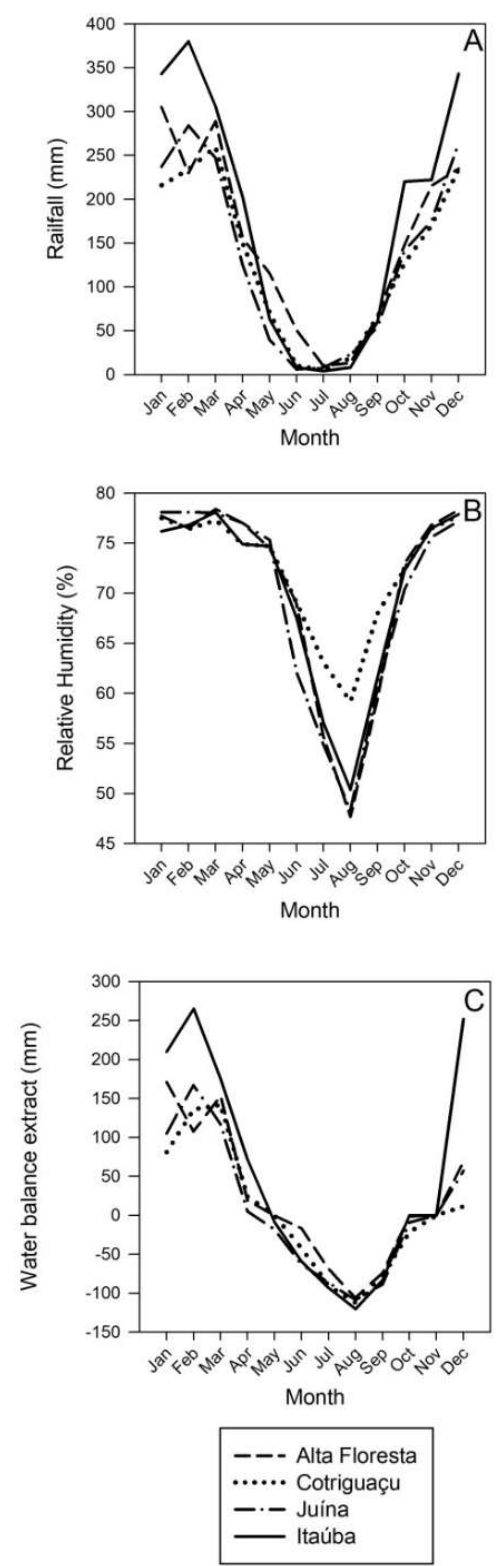

Figure 2. Mean monthly rainfall variation (A), water balance extract (B) and Relative Humidity of four sites in Mato Grosso State, from January 2007 to January 2017.

Figura 2. Variação da precipitação média mensal (A), balanço hídrico (B) e umidade relativa do ar de quatro locais do estado de Mato Grosso, de janeiro de 2007 a janeiro de 2017. 
The soils in the sites hosting the four Brazil nut tree populations in Mato Grosso State were characterized through the description of soil profiles in trenches. According to profile descriptions, soils covered with native Brazil nut vegetation were Red-Yellow Latosols or RedYellow Argisols (Table 2). Spera et al. (2019) described detailed soil morphological and mineralogy of this study.

The current study performed x-ray diffractograms of the total sample and of the samples subjected to the treatments in order to depict the mineralogical analysis. There was high intensity of kaolinite reflections in comparison to other minerals. Results of the mineralogical analyses conducted on the samples showed that they were composed of kaolinite, gibbsite, goethite, hydroxyl Al-interlayered vermiculite (HIV), anatase and mica, as shown in the diffractograms in Figure 3A. All the samples presented reduced HIV rates. Goethite was found at very low rates in all samples and its presence was evidenced by a small reflection, which was only seen in the total sample.

Soil texture ranged from very clayey to medium sandy; and soils belonging to the medium textural and medium sandy classes prevailed in the studied sites. A single profile was identified as very clayey in Cotriguaçu County, MT.

The colors of these soils varied among dark-brown, dark reddish-brown, grayish-brown and light brown at horizon A, whose thickness ranged from 8 to $29 \mathrm{~cm}$. As for soils in horizon $\mathrm{B}$, reddish-brown and yellowish-red prevailed in horizon $\mathrm{Bw}$ in latosols, whereas brown to reddish-yellow prevailed in horizon Bt of argisols. The effective depth of these soils varied from 1.80 to $2.90 \mathrm{~m}$ in latosols, and from 0.85 to $1.80 \mathrm{~m}$ in argisols (Table 3 ). The drainage in these soils varied from poorly to strongly drained (Table 4) and mineralogy showed kaolinite and gibbsite in the soils (Table 3).

Table 2. Pedological classification, locations and geographic coordinates of soil profiles described at sites hosting Brazil nut trees in the present study.

Tabela 2. Classificação pedológica, local e coordenadas geográficas dos perfis de solos descritos nos locais de ocorrência de castanheirasdo-brasil no presente estudo.

\begin{tabular}{|c|c|c|}
\hline Profile & County & Coordenates and altitude \\
\hline $\begin{array}{l}\text { Red-Yellow Latosol Dystrophic Typic (Typic Dystrophic Haplustox), moderate A, } \\
\text { medium texture, flat relief, equatorial subperenifolia forest. }\end{array}$ & Itaúba & $\begin{array}{c}09^{\circ} 49^{\prime} 11^{\prime \prime} \mathrm{S} / 58^{\circ} 16^{\prime} 03^{\prime \prime} \mathrm{W} \\
\text { alt. } 384 \mathrm{~m}\end{array}$ \\
\hline $\begin{array}{l}\text { Plinthosol Argiluvic Dystrophic Arenic (Arenic Dystrophic Plinthustox), sandy / } \\
\text { sandy loam texture, moderate A, slightly-wavy relief, tropical subperenifolia forest. }\end{array}$ & Juína & $\begin{array}{c}11^{\circ} 36^{\prime} 39^{\prime \prime} \mathrm{S} / 58^{\circ} 36^{\prime} 42^{\prime \prime} \mathrm{W} \\
\text { alt. } 295 \mathrm{~m}\end{array}$ \\
\hline $\begin{array}{l}\text { Red-Yellow Argisol Dystrophic Nitic (Dystrophic Kandustult), moderate A, } \\
\text { medium texture, wavy relief, tropical subperenifolia forest. }\end{array}$ & Juína & $\begin{array}{c}11^{\circ} 36^{\prime} 40^{\prime \prime} \mathrm{S} / 58^{\circ} 36^{\prime} 39^{\prime \prime} \mathrm{W} \\
\text { alt. } 305 \mathrm{~m}\end{array}$ \\
\hline $\begin{array}{l}\text { Red-Yellow Latosol Dystrophic Alic (Dystrophic Haplustult), moderate A, very } \\
\text { clavey texture, flat relief, equatorial subperenifolia forest. }\end{array}$ & $\begin{array}{l}\text { Alta } \\
\text { Floresta }\end{array}$ & $09^{\circ} 56^{\prime} 25^{\prime \prime} \mathrm{S} / 56^{\circ} 20^{\prime} 15^{\prime \prime}, \mathrm{W}$ \\
\hline $\begin{array}{l}\text { Red-Yellow Latosol Dystrophic Alic (Typic Dystrophic Haplustox), moderate A, } \\
\text { very clayey texture, flat relief, equatorial subperenifolia forest. }\end{array}$ & Cotriguaçu & $\begin{array}{c}09^{\circ} 49^{\prime} 16^{\prime \prime} \mathrm{S} / 58^{\circ} 17^{\prime} 22^{\prime \prime} \mathrm{W} \\
\text { alt. } 259 \mathrm{~m}\end{array}$ \\
\hline $\begin{array}{l}\text { Red-Yellow Argisol Dystrophic Abrupt (Abrupt Dystrophic Haplustult), moderate } \\
\text { A, alic, medium/clayey texture, flat relief, equatorial subperenifolia forest. }\end{array}$ & Cotriguaçu & $\begin{array}{c}09^{\circ} 49^{\prime} 11^{\prime \prime} \mathrm{S} / 58^{\circ} 16^{\prime} 03^{\prime \prime} \mathrm{W} \\
\text { alt. } 247 \mathrm{~m}\end{array}$ \\
\hline
\end{tabular}

A

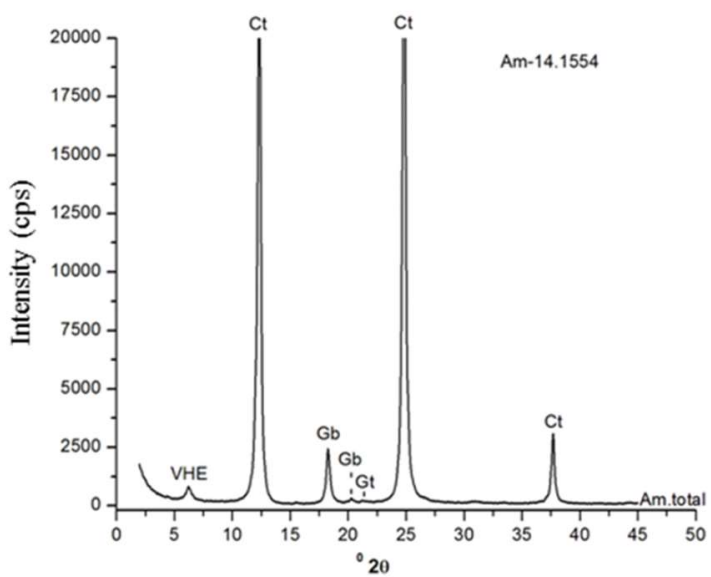

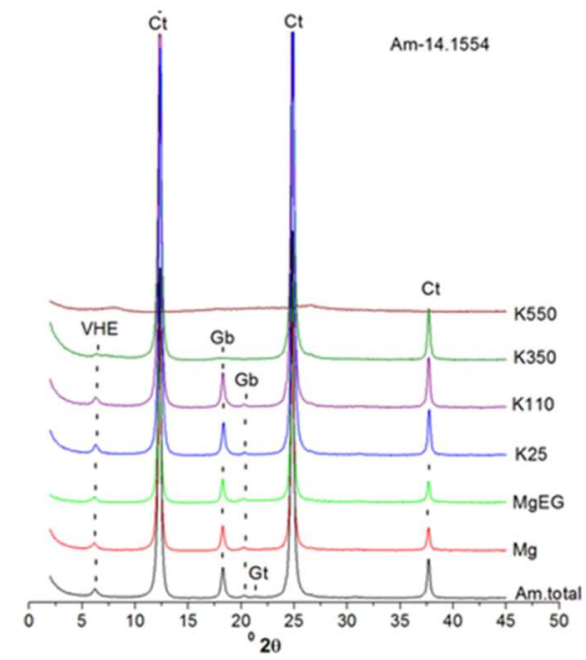

Figure 3. X-ray diffraction showing the clay fraction of the total sample (A), and the clay fraction of the total sample and of treated samples (B) from the Bw1 layer of the Red-Yellow Latosol in Itaúba County - MT. Oriented mounting. Radiation Cu K $\alpha$. HIV-vermiculite interlayered with hydroxy-Al; Ct-kaolinite; Gb-gibbsite; Gt-goethite. Predominant minerals: kaolinite and gibbsite. Am. total - untreated sample, Mg and MgEG - deferrified, magnesium-saturated sample subsequently solvated in Ethylene Glycol and scanned under both conditions. K25, K110, K350 and K550 - deferrified, potassium-saturated sample scanned at room temperature $\left(25^{\circ} \mathrm{C}\right)$ and, after heating, scanned at marked temperatures.

Figura 3. Difratograma de raios-X da fração argila da amostra total. (A) e da fração argila da amostra total e amostras submetidas aos tratamentos. Montagem orientada. Radiação Cu K- $\alpha$. VHE-vermiculita com hidróxi-Al entrecamadas; Ct-caulinita; Gb-gibbsita; Gt-goethita. Minerais predominantes: caulinita e gibbsita. Am. total - amostra não tratada, Mg e MgEG - amostra desferrificada, saturada com magnésio 
e, posteriormente, solvatada com Etileno Glicol, com varreduras executadas em ambas as condições. K25, K110, K350 e K550 - amostra desferrificada e saturada com potássio, com varreduras executadas à temperatura ambiente $\left(25^{\circ} \mathrm{C}\right)$ e, após aquecimento, nas temperaturas assinaladas.

Table 3. Effective soil depth, geology and mineralogy of soil profiles described in sites hosting Brazil nut trees in the present study.

Tabela 3. Profundidade efetiva do solo, geologia e mineralogia dos perfis de solos descritos em locais de ocorrência das populações de castanheira-do-brasil avaliadas.

\begin{tabular}{|c|c|c|c|c|}
\hline Profile & County & Effective soil depth & Geology & Mineralogy \\
\hline Red-Yellow Latosol Dystrophic Typic & Itaúba & $290 \mathrm{~cm} \mathrm{+}$ & $\begin{array}{l}\text { Pre-Middle Cambrian, } \\
\text { Dardanelle Formation. }\end{array}$ & Kaolinite -gibbsite \\
\hline Plinthosol Argiluvic Dystrophic Arenic & Juína & $\begin{array}{l}100 \mathrm{~cm} \text { up to the } \\
\text { water table }\end{array}$ & $\begin{array}{l}\text { Cretaceous, Utiariti } \\
\text { Formation }\end{array}$ & Kaolinite-gibbsite \\
\hline Red-Yellow Argisol Dystrophic Nitic & Juína & $180 \mathrm{~cm} \mathrm{+}$ & $\begin{array}{c}\text { Cretaceous, Utiariti } \\
\text { Formation }\end{array}$ & Kaolinite-gibbsite \\
\hline Red-Yellow Latosol Dystrophic Alic & Alta Floresta & $180 \mathrm{~cm}+$ & $\begin{array}{l}\text { Archaean. Xingu Complex. } \\
\text { Metamorphic granites. }\end{array}$ & Kaolinite-gibbsite \\
\hline Red-Yellow Latosol Dystrophic Alic & Cotriguaçu & $190 \mathrm{~cm}+$ & $\begin{array}{l}\text { Archaean. Xingu Complex. } \\
\text { Metamorphic granites. }\end{array}$ & Kaolinite-gibbsite \\
\hline Red-Yellow Argisol Dystrophic Abrupt & Cotriguaçu & $85 \mathrm{~cm}+$ & $\begin{array}{l}\text { Archaean. Xingu Complex. } \\
\text { Metamorphic granites. }\end{array}$ & Kaolinite-gibbsite \\
\hline
\end{tabular}

Table 4. Aluminum saturation, drainage, and textural relation of soil profiles in the present study.

Tabela 4. Saturação de alumínio, drenagem e relação textural dos perfis de solo no presente estudo.

\begin{tabular}{lccc}
\multicolumn{1}{c}{ Profile } & County & Al saturation & Drainage \\
\hline Red-Yellow Latosol Typic Dystrophic & Itaúba & High & Significantly drained \\
Plinthic Argiluvic Arenic Dystrophic & Juína & Very high & Poorly drained \\
Red-Yellow Argisol Nitic Dystrophic & Juína & Very high & Well drained \\
Red-Yellow Latosol Dystrophic Alic & Alta Floresta & Very high & Well drained \\
Red-Yellow Latosol Dystrophic Alic & Cotriguaçu & Very high & Significantly drained \\
Red-Yellow Argisol Dystrophic Abrupt & Cotriguaçu & Low to high & Moderately drained \\
\hline
\end{tabular}

The complete and detailed results of the chemical and physical analyses are very extensive and would take more space than that allowed in a scientific article; thus, they can be accessed in the paper of Spera et al. (2019). These results, however, indicate dystrophic soils showing low P, K, Ca and $\mathrm{Mg}$ levels, acid $\mathrm{pH}$, low base saturation, low CEC, and lowto-high aluminum saturation.

The diffractograms of all four analyzed sites were very similar; there was variation in the intensity of the reflections, only. The relative predominance among the minerals found in the soil sites (kaolinite, gibbsite, goethite, hydroxyl Alinterlayered vermiculite (HIV), anatase and mica), as well as the reduced occurrence of some minerals, can be seen in the diffractograms (Figure 3B), through the diagnostic reflections of each mineral. As it was previously mentioned, the diffractograms are presented in the following order: untreated sample (Am.total); deferrified, magnesiumsaturated sample subsequently solvated in ethylene glycol (MgEG); deferrified, potassium-saturated sample subjected to readings at room temperature (K25) and, after heating, at marked temperatures (K110, K350 and K550).

\section{DISCUSSION}

Rainfall amount can directly affect fruit productivity in native Brazil nut trees and higher fruit yield can be observed when accumulated rainfall is high during the dry season, from May to September (KAINER et al. 2007; IVANOV et al. 2018). No differences were found between rainfall amounts sufficiently to affect fruits production.

All the soils described in the present study naturally showed low fertility; they were acidic, highly saturated with aluminum, which is toxic to plants, and showed low phosphorus, potassium, calcium, magnesium and sulfur availability. However, they were deep, well-drained soils lacking stoniness and cragginess, whose relief varied from flat/slightly wavy to wavy. These soils originate from several geological formations and lithologies (Table 3); they changed from the Archean to the Cretaceous period, according to the Secretary of State Planning and General Coordination of Mato Grosso State (CAMARGO, 2011).

Regarding soil mineralogy, the soils identified in the present study showed kaolinite clay predominance. Guerreiro et al. (2017) studying the spatial variability of soil physical and chemical aspects in the Brazilian Amazon found a stronger spatial relationship with silt, clay, macroporosity, $\mathrm{pH}$, phosphorus, zinc, and copper in Brazil nut tree stand.

Soils in the Amazon rainforest often differ from Cerrado soils because they show predominance of kaolinite clay, whereas Cerrado soils are predominantly oxidic ( $\mathrm{Fe}$ and $\mathrm{Al}$ oxides), as described by Schaefer et al. (2017).

The preference or occurrence of Brazil nut trees in nonoxidic soils, which are commonly found in Amazonia, may allow inferring that the species does not find suitable soil and/or climate conditions for Brazil nut tree development in Cerrado environments, whose soils are predominantly oxidic (SPERA et al., 2019). This information is important at the time to define areas for the cultivation of non-native commercial Brazil nut tree. Clay; Clement (1993) recommends cultivating the species only in areas where it naturally grows.

The relationship between soil conditions and Brazil nut trees fruiting has not yet been stablished (ZUIDEMA, 2003). The native populations of Brazil nut trees are preferably located in clayey or sandy-loamy soils, more frequently in medium to heavy texture. Ivanov et al. (2018) observed that 
Brazil nut trees growing in shallow clayey soils produce less seeds when compared to trees growing on deep soils with loam and clay and loam sandy. Müller; Caizavara (1989) and Kainer et al. (2007) founded positive correlations among the number of fruits produced per tree, cation exchange capacity (CTC) and leaf concentrations of phosphorus.

\section{CONCLUSIONS}

The studied sites presented similar climate features during the analyzed period. They also showed low spatial variability (accumulated rainfall, air temperature and relative air humidity).

The soils described at the sites hosting Brazil nut trees in Mato Grosso State are acidic; they showed sandy-to-medium texture, low natural fertility and, sometimes, high aluminum content; however, they were kaolinitic or kaolinite-gibbsitic soils, fact that differs them from most Cerrado soils.

The soils prevailing in the herein assessed sites belong to classes such as Red-Yellow Argisol Dystrophic and RedYellow Latosol Dystrophic, with flat to smoothly wavy relief. The high toxic aluminum saturation found in the soil surface samples collected in the herein investigated sites indicated that species growth and development were not affected by the chemical attribute of the soil.

Brazil nut trees were not found in soils with shallow water tables, although the occurrence of the species was already recorded in shallow non-soaked soil.

Based on rainfall amount during the dry season, water deficit and soil properties data in the assessed sites, regions such as Alta Floresta and Cotriguaçu showed favorable conditions for greater Brazil nut trees productivity, and may be indicated for the commercial planting of species.

\section{REFERENCES}

ALVARES, C. A.; STAPE, J. L.; SENTELHAS, P. C.; GONÇALVES, J. L. M.; SPAROVEK, G. Köppen's climate classification map for Brazil. Meteorologische Zeitschrift, Berlin, v. 22, n. 6, p. 711-728, 2014. DOI: https://dx.doi.org/10.1127/0941-2948/2013/0507

BARNHISEL, R. I.; BERTSCH, P. M. Chlorites and hydroxy-interlayered vermiculite and smectite. Minerals in Soil Environments, Madison, v. 1, n. 2, p. 729-788, 1989. https://dx.doi.org/10.2136/sssabookser1.2ed.c15

BERRY, L. G. Joint Committee on Powder Diffraction Standards-JCPDS: selected powder diffraction data for minerals, 1. ed. Philadelphia, Pennsylvania, 1974. $17 \mathrm{p}$.

BRANCO, P. M. Dicionário de mineralogia e gemologia. Oficina de Textos, São Paulo, São Paulo, 2008. 680 p.

BRIENEN, R. J. W; ZUIDEMA, P. A. Relating tree growth to rainfall in Bolivian rain forests: a test for six species using tree ring analysis. Oecologia, Berlin, v. 146, p. 112, 2005. DOI: https://dx.doi.org/10.1007/s00442-0050160-y

CAMArGO, L. (Org.) Atlas de Mato Grosso. Governo do Estado de Mato Grosso. Secretaria de Planejamento e Coordenação Geral. SEPLAN/MT, Cuiabá, MT: Entrelinhas, 2011. $96 \mathrm{p}$.

CLAY, J. W; CLEMENT, C. R. Food and Agriculture Organization of the United Nations (FAO). 1993. p. 1-228. Available on: <http://www.fao.org/docrep/v0784e/v0784e05.htm).
Accessed on: 07/08/2017.

EMBRAPA_EMPRESA BRASILEIRA DE PESQUISA AGROPECUÁRIA. Sistema brasileiro de classificação de solos. 5. ed. rev. e aum. Brasília: Centro Nacional de Pesquisa de Solos, 2018. 356 p.

GRIM, R. E. Crystal Structures of Clay Minerals and Their X-Ray Identification. Earth-Science Reviews, Amsterdam, v. 18, n. 1, p. 84-85, 1982. DOI: https://dx.doi.org/10.1016/0012-8252(82)90013-7

GUERREIRO, Q. L. M.; JÚNIOR, R. C. O.; DOS SANTOS, G.; RUIVO, M. L.; BELDINI, T.; CARVALHO, E. J. M.; DA SILVA, K.; GUEDES, M. C.; SANTOS, P. R. Spatial variability of soil physical and chemical aspects in a Brazil nut tree stand in the Brazilian Amazon. African Journal of Agricultural Research, v. 12, n. 4, p. 237-250, 2017.

IBGE. Produção da extração vegetal e da silvicultura. $2017 . \quad$ Available on: (http://www.ibge.gov.br/home/estatistica/pesquisas/p esquisa_resultados.php?id_pesquisa=45). Accessed on $11 / 06 / 2019$

IVANOV, G. B.; FLEIG, F. D.; TONINI, H. Fatores edafoclimáticos relacionados à produção de sementes em castanhais nativos de Roraima. Pesquisa Florestal Brasileira, Colombo, v. 38, p. 1-6, 2018.

KÄMPF, N.; CURI, N. Argilominerais em solos brasileiros. In: CURI, N.; MARQUES, J. J.; GUILHERME, L. R. G.; LIMA, J. M. DE; LOPES, A. S.; ALVAREZ V., V. H. (Ed.). Tópicos em ciência do solo. Viçosa: Sociedade Brasileira de Ciência do Solo, 2003. cap. 3. p. 1-54.

KAINER, K. A.; WADT, L. H. O.; STAUDHAMMER, C. L. Explaining variation in Brazil nut fruit production. Journal of Tropical Ecology, v. 22, p. 147-154, 2007. DOI: https://dx.doi.org/10.1016/j.foreco.2007.05.024

LORENZI, H. Árvores brasileiras: manual de identificação de plantas arbóreas nativas do Brasil. 7 . ed. São Paulo: Instituto Plantarum, 2016. 1 v. 384 p.

MEHRA, O. P.; JACKSON, M. L. Iron oxide removal from soils and clays by a dithionite-citrate system buffered with sodium bicarbonate. In: Proceedings of the Seventh National Conference on Clays and Clay Minerals, 2013 Amsterdam. Annals... Amsterdam: Clays and Clay Minerals, 2013. p. 317-327. DOI: https://doi.org/10.1016/B978-0-08-009235-5.50026-7

MÜLLER, C. H.; CAIZAVARA, B. B. G. Castanha-doBrasil. Belém: CPATU, 1989. 6p. (Informações básicas, 11).

ROCKWELL, C. A.; GUARIGUATA, M. R.; MENTON, M.; QUISPE, E. A.; QUAEDVLIEG, J.; WARRENTHOMAS, E.; SILVA, H. F.; ROJAS, E. E. J.; ARRUNÁTEGUI, J. A. H. K.; VEJA, L. A. M.; VERA, O. R.; HANCCO, R. Q.; TITO, J. F. V.; PANDURO, B. T. V. AND SALAS, J. J. Y. Nut production in Bertholletia excelsa across a logged forest mosaic: Implications for multiple forest use. Plos One, v. 10, n. 8, e0135464, 2015. DOI: https://doi.org/10.1371/journal.pone.0135464

SCHAEFER, C. E. G. R.; LIMA, H. N.; TEIXEIRA, W. G.; VALE JUNIOR, J. F.; SOUZA, K. W.; CORRÊEIA, G. R.; MENDONÇA, B. A. F.; AMARAL, E. F.; CAMPOS, M. C. C.; RUIVO, M. L. P. Solos da Região Amazônica. IN: CURI, N.; KER, J. C.; NOVAIS, R. F.; VIDAL-TORRADO, P.; SCHAEFER, C. E. G. R. (Ed.). 
Pedologia: solos dos biomas brasileiros. Viçosa: Sociedade Brasileira de Ciência do Solo, 2017. cap. 3. p. 111-175.

SILVA, F.C. Manual de análises químicas de solos, plantas e fertilizantes. Centro Nacional de Pesquisa de Solos, Rio de Janeiro, 2009. 624 p.

SOUZA, A. P.; MOTA, L. L.; ZAMADEI, T.; MARTIM, C. C.; ALMEIDA, F. T.; PAULINO, J. Classificação climática e balanço hídrico climatológico no estado de Mato Grosso. Nativa, Sinop, v. 1, n. 1, p. 34-43, 2013. DOI: $\quad$ http://dx.doi.org/10.14583/23187670.v01n01a07

SPERA, S. T.; MAGALHÃES, C. A. S.; BALDONI, A. B.; CALDERANO, S. B. Caracterização pedológica de locais de estudo de populações naturais de castanheira-do-Brasil no estado de Mato Grosso. Nativa, Sinop, v. 7, n. 2, p. 145-161, 2019. http://dx.doi.org/10.31413/nativa.v7i2.6502

TEIXEIRA, P. C.; DONAGEMMA, G. K.; FONTANA, A.; TEIXEIRA, W. G. Manual de métodos de análise de solo. 3. ed. rev. e aum. Brasília: Embrapa, 2017. 574 p.

THOMAS, E.; CAICEDO, C. A.; LOO, J.; KINDT, R. The distribution of the Brazil nut (Bertholletia excelsa) through time: from range contraction in glacial refugia, over human-mediated expansion, to anthropogenic climate change. Boletim do Museu Paraense Emílio Goeldi, Ciências Naturais, Belém, v. 9, n. 2, p. 267-291, 2014.

THORNTHWAITE, C. W. An approach towards a rational classification of climate. Geographical Review, v. 38, n. 1, p. 55-94, 1948 . DOI: https://dx.doi.org/10.2307/210739

426 ZUIDEMA, P. A. Ecology and management of the Brazil nut tree (Bertholletia excelsa). Utecht: Promab, 2003. 111 p. (Scientific series, 6). 